\title{
Is additive manufacturing a magic bullet to resupply lacking PPE? Producing respirators and face shields during COVID-19 pandemic: A systematic review
}

\section{Czy druk 3D to skuteczny sposób na dostarczenie brakujących środków ochrony osobistej? Produkcja maseczek ochronnych i przyłbic podczas pandemii COVID-19 - przegląd systematyczny}

\author{
Jakub Rzeszuto ${ }^{1, A-F}$, Patryk Kaczor ${ }^{1, A, C, D, F}$, Bernadetta Kosztulska ${ }^{1, A, C, D, F}$, Iwona Handzlik ${ }^{1, A, C, D, F}$, Szymon Suwała ${ }^{2, A, E, F}$, Roman Junik ${ }^{2, A, E, F}$ \\ 1 Student Research Club of Evidence-Based Medicine, Department of Endocrinology and Diabetology, Collegium Medicum in Bydgoszcz, Nicolaus Copernicus University in Torun, \\ Bydgoszcz, Poland \\ 2 Department of Endocrinology and Diabetology, Collegium Medicum in Bydgoszcz, Nicolaus Copernicus University in Torun, Bydgoszcz, Poland \\ A - research concept and design; B - collection and/or assembly of data; $C$ - data analysis and interpretation; \\ $D$ - writing the article; $E$ - critical revision of the article; $F$ - final approval of the article
}

\section{Address for correspondence \\ Jakub Rzeszuto}

E-mail: jakub.rzeszuto@onet.pl

\section{Funding sources}

None declared

Conflict of interest

None declared

Received on 0ctober 22, 2021

Reviewed on November 29, 2021

Accepted on November 29, 2021

Published online on December 15, 2021

Cite as

Rzeszuto J, Kaczor P, Kosztulska B, Handzlik I, Suwała S, Junik R. Is additive manufacturing a magic bullet to resupply lacking PPE? Producing respirators and face shields during COVID-19 pandemic: A systematic review.

Polim Med. 2021;51(2):91-102. doi:10.17219/pim/144329

DOI

10.17219/pim/144329

Copyright

○ 2021 by Wroclaw Medical University

This is an article distributed under the terms of the

Creative Commons Attribution 3.0 Unported (CC BY 3.0)

(https://creativecommons.org/licenses/by/3.0/)

\begin{abstract}
Coronavirus Disease 2019 (COVID-19) pandemic caused an increase in the demand for personal protective equipment (PPE) and disruptions in production chains, resulting in an acute shortage of PPE. A possible solution to this problem was additive manufacturing (AM) technology - allowing for a quick start of the production of PPE and potentially able to meet the demand until the production is restored. In addition, AM allows for the production of PPE prototypes with potentially greater comfort of use or degree of protection. In order to assess the production of PPE in AM during the COVID-19 pandemic, previously published articles in this field were analyzed. After analyzing abstracts and full texts, 30 original works were selected from the initially collected 487 articles.

Based on the analyzed literature, it was found that there are not enough studies comparing traditional and AM PPE as well as not enough comparisons of the different types of AM PPE with each other. In many cases, researchers focused only on the subjective assessment of the comfort of using PPE, without assessing their effectiveness in preventing infections. Despite that, AM has a great potential to quickly produce lacking PPE. Respirators and shields made by AM were rated by the vast majority of users as comfortable to wear. Some of the respirators could be adapted to a specific user, by designing on the basis of a face scan or after warming up the finished print and modeling the shape.
\end{abstract}

Key words: COVID-19, personal protective equipment, three-dimensional printing 


\section{Streszczenie}

Pandemia COVID-19 doprowadziła do jednoczesnego wzrostu zapotrzebowania na środki ochrony indywidualnej (ŚOI) oraz przerwania łańcuchów produkcji, co poskutkowało dotkliwym niedoborem ŚOl. Możliwym rozwiązaniem tego problemu okazała się technologia druku 3D, pozwalająca na szybkie rozpoczęcie wytwarzania ŚOl i potencjalnie mogąca zaspokoić popyt do czasu przywrócenia produkcji dotychczasowymi metodami. Ponadto technologia druku 3D pozwala na wykonanie prototypów ŚOl o potencjalnie większym komforcie użytkowania lub stopniu ochrony.

W celu oceny produkcji ŚOI w technologii druku 3D w trakcie pandemii COVID-19, przeanalizowano dotychczas opublikowane artykuły w tej dziedzinie. Po analizie abstraktów oraz pełnych tekstów, z początkowo zebranych 487 artykułów wyłoniono 30 oryginalnych prac.

Na podstawie przeanalizowanego piśmiennictwa stwierdzono, że brakuje badań porównujących tradycyjne oraz wydrukowane ŚOl oraz porównań wykonanych już ŚOl między sobą. Ponadto w wielu przypadkach badacze skupili sięjedynie na subiektywnej ocenie komfortu użytkowania ŚOl, bez oceny ich skuteczności w ochronie przed zakażeniem. Pomimo tych zastrzeżeń druk 3D ma duży potencjał szybkiego wyprodukowania brakujących ŚOl. Wykonane w tej technologii maseczki oraz przyłbice ochronne były oceniane przez zdecydowaną większość użytkowników jako komfortowe w noszeniu. Część maseczek ochronnych dawała możliwość dostosowania do konkretnego użytkownika poprzez zaprojektowanie na podstawie skanu twarzy lub po rozgrzaniu gotowego wydruku i wymodelowaniu kształtu.

Słowa kluczowe: COVID-19, środki ochrony osobistej, druk trójwymiarowy

\section{Introduction}

In December 2019, severe acute respiratory syndrome coronavirus 2 (SARS-CoV-2) was first isolated in Wuhan, China. Since then, the virus has spread all over the world causing a global outbreak. In March 2020, the World Health Organization (WHO) announced the current situation as pandemic with overall 118,000 cases worldwide. ${ }^{1}$ The increasingly high numbers of Coronavirus Disease 2019 (COVID-19) cases made it difficult to ensure protection not only for patients but also for healthcare workers. Wang et al. proved that $29 \%$ of in-hospital infections had health professionals involved. ${ }^{2}$

The virus spreads by respiratory droplets, e.g., coughing and sneezing, and is present in the upper respiratory tract for approx. 2-10 days before any symptoms appear. ${ }^{3}$ Face shields combined with additional mouth and nose masks have been recommended to reduce the risks of inhalational exposure, specifically when performing activities with aerosol formations. Considering that no causative treatment is available, prevention has become the main objective. These aspects made it a necessity to cover the face and disinfect all used surfaces. ${ }^{4,5}$ The global situation made it necessary for everyone to gain access to personal protective equipment (PPE). The pandemic created a great shortage in PPE and additive manufacturing (AM) was an alternative solution to this problem. Face shields are PPE devices used in many professions for protection of the face area from splashes and sprays of body fluids. Nonetheless, to be effective during the COVID-19 pandemic, they should be used with other protective equipment. ${ }^{6,7}$

The traditional manufacturing industries almost shut down because of lockdown measures, so AM stepped in to supply medical professionals. The steps for AM production of the PPE consist of creating or obtaining the project for the parts, and producing and assembling them with the additional required supplies. Additive manufacturing is a process which involves adding the material layer by layer in line with a computer-aided design model. ${ }^{8}$ Models can be created using numerous 3D design software. Eventually, the designed model is conveyed to a slicer software to set production parameters, such as the height of the layers and the thickness of the shell of the models. Finally, the AM machine uses the resulting file to manufacture the model. The last step is post-processing: for example, removal of supports and sanding. ${ }^{9}$ There are many methods of AM such as fused deposition modeling (FDM), stereolithography (SLA) and digital light processing. However, most of the analyzed papers described the use of FDM technology.

\section{Materials and methods}

A systematic literature review was done using the PubMed and Scopus databases. The search strategy was extensive to ensure that no significant articles were missed. The search algorithm consisted of 3 conditions, all of which had to be met: 1) connected with AM ("additive manufacturing", "3D printing" and names of individual AM techniques); 2) connected with COVID-19 pandemic ("covid 19", "sars cov 2", "pandemic", "coronavirus", "severe acute respiratory syndrome coronavirus 2"); 3) date of publication between November 1, 2019 and July 31, 2021, to exclude publications from before the outbreak of the COVID-19 pandemic. Also, in the case of the Scopus database, due to its multidisciplinary characteristics, the search criteria have been narrowed down to the Medicine category.

Only original papers were selected. Publications written in languages other than English or without a full article available were excluded from the analysis. Papers about virtual 3D rendering or modeling without manufactured AM parts were not included. Only articles where AM technology was used to produce or assist with testing and designing face respirators or face shields during the COVID-19 pandemic were selected. 
The research team was divided into 2 workgroups. At each step, where biased selection had to be taken into consideration (2 stages: abstract screening and full-text screening), each group separately performed a manual selection. After that, the differences in the assessment were summarized and a discussion was held between both groups to establish a consensus. If no consensus was possible to achieve at the abstract screening step, the final decision was postponed until the full text was analyzed.

The articles that passed the full-text review were analyzed in detail using the table of evidence to present the relevant features and results of the study. Based on the results commonly reported in literature, the following variables were included: AM-made PPE types, analyzed PPE parameters, number of participants, test duration, test results, AM technology, and machinery and materials used. Detailed procedure of the article screening is presented in Fig. 1.

\section{Face mask design}

Many mask designs have come to light during the pandemic. Most of them consist of 3 reusable parts: the mask base, the filter grill and the filter insert (Fig. 2A). The mask straps are assembled using phlebotomy straps, Velcro/elastic bands or simple strings. ${ }^{10-13}$ The disposable filter is placed between the filter insert and the filter grill. The filters inserted were: nano-sized Cumminis, IsoGuard filters, FFP2/FFP3 and HEPA. The FDM mask offered the possibility of reshaping, using both microwave and hot water since it is thermoplastic - this ensures a better fit on a user's face. ${ }^{14}$ Face masks can be also custom-made by using face scanning programs. The obtained data are then used to design a 3D model. ${ }^{11}$

The limitation of available commercial standard masks is the poor variety of face shape. To ensure better protection, the design can be personalized. Fit testing of respirators is mandatory in some workplaces. ${ }^{15}$ In particular, it is essential while performing procedures posing high risk of virus exposition, such as nasolaryngoscopy. ${ }^{16}$

Many researchers took advantage of computer-aided design software to implement some improvements in their projects. Helman et al. used the open-source design and modified it, enclosing more of the midface and adding 2 ports (they used software such as Blender (www.blender. org) and Fusion 360 (https://www.autodesk.com/products/ fusion-360/overview)). ${ }^{17}$ Piombino et al. used Meshmixer (www.meshmixer.com), which is available for free - that was important during the episodes of lack of PPE during the COVID-19 pandemic. ${ }^{18}$ Shaheen et al. and Swennen

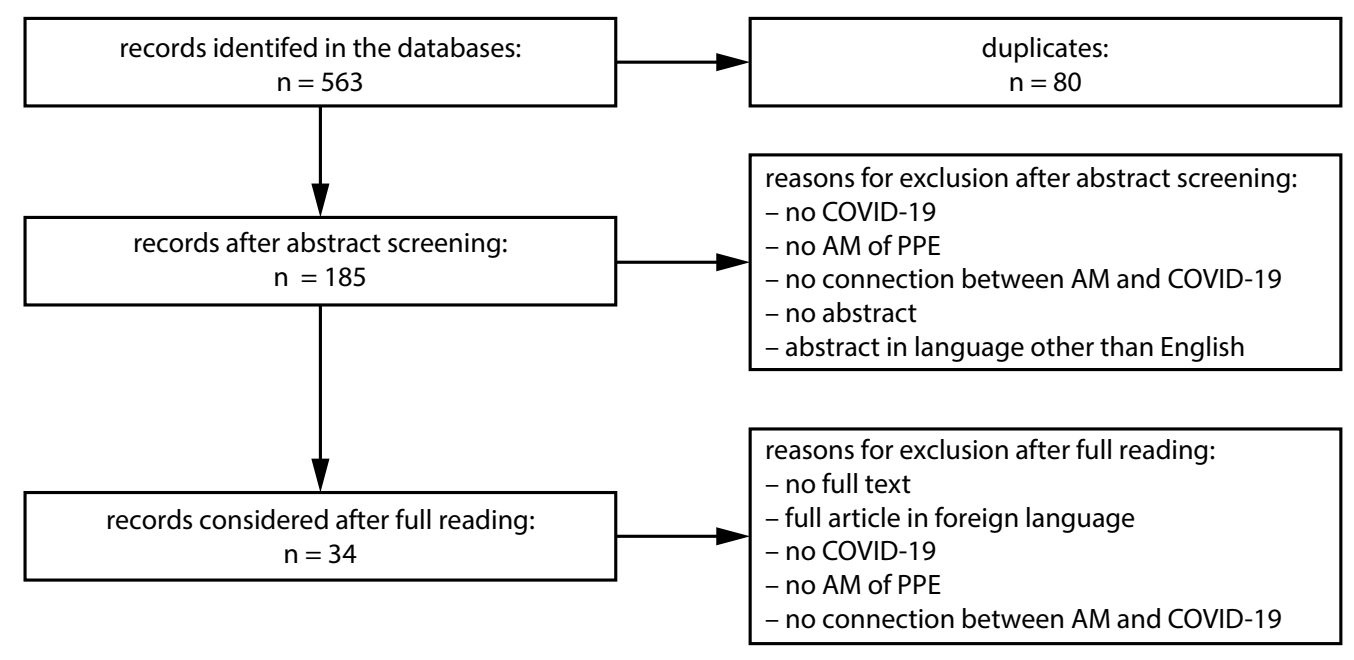

Fig. 1. Algorithm of articles selection

COVID-19 - Coronavirus Disease 2019; AM - additive manufacturing; PPE - personal protective equipment.

A 1

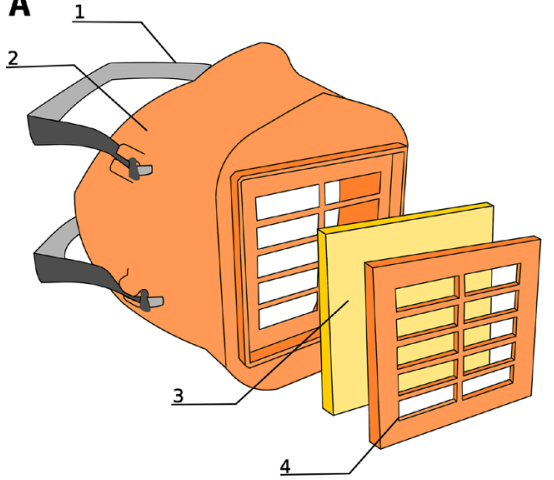

B

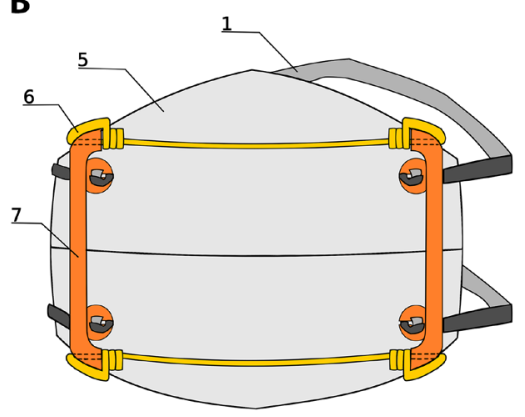

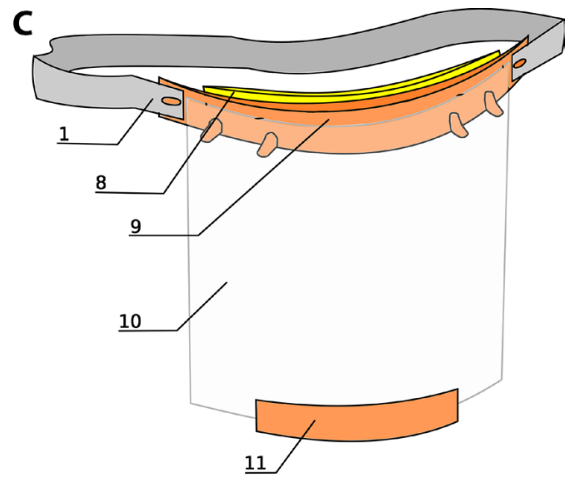

Fig. 2. A. An example of additive manufacturing (AM)-made face mask: 1 - straps, 2 - mask base, 3 - filter insert, 4 - filter grill; B. An example of AM-made face frame: 1 - straps, 5 - commercially available respirator, 6 - wire, 7 - frame; C. An example of AM-made face shield: 1 - straps, 8 - adhesive foam, 9 - headband, 10 - transparent layer, 11 - chin support 
et al. used VECTRA Face Sculptor ${ }^{\circledR}$ to automatically put key landmarks on soft tissues on the face. ${ }^{5,11}$ Davies et al. added port to existing face mask model (Copper 3D Nanohack; Copper 3D, Santiago, Chile) with Materialise Mimics software (www.materialise.com). ${ }^{16}$

There are various methods of minimizing the risk of virus transmission. Some designs (e.g., Helman et al.) were filled with vacuum seal between the face and the mask. ${ }^{17}$ As tightness of the face mask increases, the protection becomes more effective. Another way to optimize the fitting of PPE is $3 \mathrm{D}$ face scanning. Swennen et al. used new generation smartphone with 2 cameras supported with Bellus3D app to generate individual 3D face scans. ${ }^{11}$ Shaheen et al. used 3D camera VECTRA ${ }^{\circledR}$ H1 (Canfield Scientific Inc., Parsippany, USA), ${ }^{5}$ while Piombino et al. used smartphone and Bellus3D application (Bellus3D, Campbell, USA). ${ }^{18}$ These customized face masks can be complemented with a disposable filter membrane support, also designed using computeraided design - those masks become consistent PPE after quick assembly. Both elements are connected with each other using screw fixation, which also improves tightness. ${ }^{11}$

Another interesting design concept is a project whose originators are $\mathrm{Ng}$ et al. Their design was adopted from a simple silicon respirator and was modified and produced with silicone injection molding. This one provides tightness and good filtration; it is also equipped with a port for a pleated-membrane respiratory filter. ${ }^{19}$

Anwari et al. designed a reusable mask, called a "simple silicone mask" (SSM). The SSM was invented for the appropriate fitting to a user's face shape. This was achieved by designing a special harness added to the basic mask construction and using silicone that provided air-tight seal. The design was supplied with a heat-moisture exchange filter. The mask was cast using original FDM molds. ${ }^{20}$

Bezek et al. found that the application of an epoxy sealant to the Stopgap respirator (made of polylactic acid (PLA)) increased the filtration efficiency from $\sim 55 \%$ to a peak of $\sim 75 \% .^{21}$

\section{Face mask accessories}

Not only masks but also accessories improving their quality and effectiveness, such as mask adapters, can be produced using AM technology. The design created by ImbrieMoore et al. consisted of 3M N95 face mask (3M, Saint Paul, Minnesota) and SLA rigid cartridge with sealing flange. ${ }^{22}$ Another PPE which was complemented with AM-made accessory, the adapter, was a full-face diving mask. ${ }^{23}$

Davies et al. designed face masks and adapters that may be used by patients undergoing medical procedures, such as nasal endoscopy. When examining a patient equipped with AMmade PPE, healthcare workers are less exposed to viruses. ${ }^{16}$

McAvoy et al. described the development of the design of the FDM face frames (Fig. 2B) that prolongs the lifespan of masks and allows them to be reused. The simple design enables it to be easily molded for customization. ${ }^{24}$

\section{Face shield design}

Most of the face shields consist of 3 main parts: the head band, the transparent layer attached to the band, and string/straps and additional parts that include optional chin support and adhesive foam (Fig. 2C). In addition to the manufactured parts, straps and transparent film are needed to assemble the shield. During the usage of face shields one should have in mind that they are inadequate as an individual protection, and will not be sufficient without a face mask. ${ }^{10,25}$

In the designing process, it is crucial to adjust further properties of the face shields to special medical allocation of this PPE. Hence, the design must be adapted to the needs of medical staff during the COVID-19 pandemic, the shortage of materials and lack of time for PPE preparation. Moreover, AM can make PPE more customized. Thanks to individual design modifications, AM-made face shields have features not present in commercially available ones. ${ }^{26,27}$ For example, Critical Cover Coverall Face Shield by AlphaProTech (Markham, Canada) does not provide adequate liquid protection at the top and on the sides of the visor. ${ }^{26}$

Most of the studies focus on such parts of the design as: efficient protection (e.g., from aerosols and liquids), comfort of wearing (especially when worn for a long time), the possibility of fast assemblage of a PPE, and making it easy to manufacture. There are different methods that help to achieve these goals, for example, adjusting the length of the face shield to clinicians' needs, easy attachment, limitation of holes in the PPE, and adding the lip above the visor. ${ }^{26,27}$ The most popular face shield design in analyzed studies was PRUSA RC2.6,26,28

A much more complicated design was presented in the study conducted by Huang et al. - a design consisting of 4 elements: goggles, lenses, exact face shield, and elastic bands. The goggles are the most comprehensive part of this design, because, as any other part of the shield they must fit the user properly. They were designed in 3 sizes (large, medium and small). ${ }^{27}$

Lemarteleur et al. designed a face shield that required $3 \mathrm{~h}$ to manufacture. The project was inspired by the opensource PRUSA RC2 and PRUSA RC3 models (Prusa, Prague, Czech Republic). The headband consisted of 2 arches: one to support the forehead, the other one to deflect the shield from the face. This construction prevented from fogging and was obtained with FDM using polylactic acid (PLA). ${ }^{29}$

It is crucial to mention that not only the significant features of face shields, but also the method and efficiency of production and a potential for large-scale manufacturing are the key elements in evaluation of a particular project. ${ }^{6,25,26}$ Stacking - producing multiple parts on top of each other (they require post-processing for separation) - may be a factor providing effectiveness and reducing the costs of production. ${ }^{25,26}$ The lack of this feature may be an exclusion criterion for the design due to its impracticability. A detailed comparison of face shield designs is presented in Table 1. 
Table 1. Different face shields design comparison $6,26,30-32$

\begin{tabular}{|c|c|c|c|c|c|}
\hline Parameters & Prusa RC1 & Prusa RC2 & $\begin{array}{l}\text { 3D Face Shield V3 } \\
\text { (Budmen) }\end{array}$ & Easy 3D Face Shield & $\begin{array}{l}\text { Modified Prusa } \\
\qquad(\text { PanFab) }\end{array}$ \\
\hline Tools for assembling & DIN A4 perforator & DIN A4 perforator & DIN A4 perforator & none & $\begin{array}{l}\text { additional laser cutting } \\
\text { or rotary die cutting of } \\
\text { the transparent shield }\end{array}$ \\
\hline Weight $[g]^{*}$ & 39 & 51 & 42 & 30 & $\begin{array}{l}\text { no exact data, but } \\
\text { it was mentioned that } \\
\text { the design was based } \\
\text { on RC2 }\end{array}$ \\
\hline $\begin{array}{l}\text { Wearing comfort according } \\
\text { to analyzed articles }\end{array}$ & $\begin{array}{l}\text { worse because } \\
\text { of a clamp for } \\
\text { head frame } \\
\text { (might be too } \\
\text { tight) }\end{array}$ & $\begin{array}{l}\text { increased (when } \\
\text { compared to } R C 1 \text { ) due } \\
\text { to no clamp for head } \\
\text { frame }\end{array}$ & $\begin{array}{l}\text { less comfortable for } \\
\text { medical staff than RC2 } \\
\text { (e.g., due to rigidity) }\end{array}$ & $\begin{array}{l}\text { similarly comfortable } \\
\text { to RC2 (e.g., due } \\
\text { to lower weight) }\end{array}$ & $\begin{array}{l}\text { perceived as more } \\
\text { comfortable for } \\
\text { medical staff } \\
\text { (e.g., due to reduction } \\
\text { of tightness) than RC2 }\end{array}$ \\
\hline Anchor point & $\begin{array}{l}\text { placed lateral } \\
\text { to the headband }\end{array}$ & similar to RC1 & similar to RC1 & $\begin{array}{l}\text { visor is put into a small } \\
\text { continuous slot with } \\
\text { clamping retention }\end{array}$ & $\begin{array}{c}\text { placed in line with } \\
\text { headbands - reduction } \\
\text { of tightness }\end{array}$ \\
\hline $\begin{array}{l}\text { Dimensions and print } \\
\text { volume requirements }\left[\mathrm{mm}^{2}\right]\end{array}$ & $240 \times 240$ & $144 \times 191$ & requirements as in $\mathrm{RC} 2$ & requirements as in $\mathrm{RC} 2$ & $240 \times 305$ \\
\hline Attachment (shield to strap) & $\begin{array}{l}\text { four-point } \\
\text { attachment; } \\
\text { necessity } \\
\text { of perforation }\end{array}$ & similar to RC1 & similar to RC1 & $\begin{array}{l}\text { visor is put into a small } \\
\text { continuous slot with } \\
\text { clamping retention }\end{array}$ & $\begin{array}{l}\text { six-point attachment; } \\
\text { necessity of perforation }\end{array}$ \\
\hline $\begin{array}{l}\text { Protection from liquids } \\
\text { (during special medical } \\
\text { procedures) on the top and } \\
\text { sides of visor }\end{array}$ & $\begin{array}{l}\text { restricted } \\
\text { in the area } \\
\text { on the top } \\
\text { of the visor }\end{array}$ & similar to RC1 & no data & no data & $\begin{array}{l}\text { fin on the top } \\
\text { of headband and } \\
\text { additional plastic lip }\end{array}$ \\
\hline Additional equipment & $\begin{array}{l}\text { lower space } \\
\text { between face } \\
\text { and visors (when } \\
\text { compared } \\
\text { to } R C 2 \text { ) }\end{array}$ & $\begin{array}{l}\text { increased space } \\
\text { between face and } \\
\text { visors (when compared } \\
\text { to RC } 1 \text { ) - easier to put } \\
\text { eye or mouth-nose } \\
\text { personal protective } \\
\text { equipment (PPE) } \\
\text { (goggles, masks) }\end{array}$ & $\begin{array}{c}\text { space between face } \\
\text { and visors comparable } \\
\text { to RC2 }\end{array}$ & $\begin{array}{c}\text { space between face } \\
\text { and visors comparable } \\
\text { to RC2 }\end{array}$ & $\begin{array}{l}\text { no direct data, but } \\
\text { space between face } \\
\text { and visors regarded } \\
\text { as comparable to RC2 }\end{array}$ \\
\hline Possibility of stack printing & no & yes & no & no & no exact data \\
\hline
\end{tabular}

* fused deposition modeling (FDM) technology was used; the weight can differ depending on the type of used materials or print parameters (e.g., the number of walls, infill density).

\section{Face masks - materials}

The transmission of SARS-CoV-2 occurs primarily by droplets. Most of the studies for testing filtration efficiency use particles with the size of $300 \mathrm{~nm}$, whereas viruses are slightly smaller. ${ }^{33}$

Swennen et al. designed a reusable face mask design, which consisted of 4 elements, 2 of which were produced using selective laser sintering (SLS) and were reusable. The most important component was the mask itself, which was made of polyamide composite (PA11-SX 1450). This material has ISO/USP Class VI medical certification, which proves that there are no negative, long-term effects on the organism resulting from its use. The replaceable elements were the head fixation band and the polypropylene particle filter membrane (Moldex 8080). ${ }^{11}$

A filter project published by $\mathrm{He}$ et al. assumed the use of nanofiber mat made of 10\% PLA (polylactic acid) solution dissolved in chloroform and n,n-dimethylformamide. The main body of the filter, on which the nanofiber mat was embedded in order to strengthen and avoid damage to its fibers, was made of the same solution, previously dried for $12 \mathrm{~h}$ at $80^{\circ} \mathrm{C}$. The optimal printing temperature was $210^{\circ} \mathrm{C}$. Higher temperatures led to a loss of transparency and filtration efficiency. The effectiveness of the surgical mask (filtration efficiency at least 55\% for $700 \mathrm{~nm}$ mass median aerodynamic diameter) was exceeded with the use of 1 layer. The use of 2 layers allowed to achieve over $80 \%$ (FFP1 criteria), and the use of 4 layers - over 94\% (FFP2), in some cases even above $95 \%$ of filtration efficiency (KN95/N95). ${ }^{33}$

In case of face masks, in order to prevent the virus from getting into the respiratory tract, a suitable, close fit to the face is necessary. Rendeki et al. describe the Face Mask v. 2.0 model, in which a layer of silicone has been added to reduce air leakage at the point of contact between the mask and the face. Disinfection does not adversely affect the mechanical properties of this material, and moreover, it is long-lasting and durable. ${ }^{34}$

The design of individual face masks on the basis of a 3D face scan was proposed by Shaheen et al. VeroClear 
photopolymer, which is characterized by hardness and transparency, was used to print 6 components. The last element, a soft rim, was made of TangoPlus photopolymer, a soft transparent rubber-like material. ${ }^{5}$

Imbrie-Moore et al. shared an idea to transform one N95 face mask into 4 new masks with the same properties. They used SLA technology. The main materials of the mask adapter were multi-purpose polyurethane and biocompatible silicone. The filter was made of an N95 mask and it was attached using a nontoxic thermoplastic adhesive. ${ }^{22}$

Proper disinfection is a challenge that must be faced when using PPE made with AM technology. Vaňková et al. published an article comparing the disinfection efficiency of PLA using $96 \%$ ethanol, $70 \%$ isopropanol or $0.85 \%$ sodium hypochlorite. A suspension of bacteria and viruses (SARS-CoV-2) was applied to the reference object made of PLA. All 3 agents were effective in terms of complete decontamination against SARS-CoV-2. It is worth noting that in the case of ethanol, there was also a slight melting of filaments made of PLA. It led to a decrease in the distance between individual filaments, an increase in density and, presumably, the improvement of the filtration properties. ${ }^{35}$ Welch et al. tested several materials, including PA12, acrylonitrile butadiene styrene (ABS) and PLA. A single application by wipe of quaternary ammonium (Sani-Cloth germicidal disposable wipe), 3\% $\mathrm{H}_{2} \mathrm{O}_{2}$ and $10 \%$ bleach resulted in a complete inactivation of tested viruses, including SARS-CoV-2. However, a single wipe of $70 \%$ isopropyl alcohol led only to $>95 \%$ inactivation, as compared to $>99 \%$ effectivity of other compounds. For complete virus inactivation, stronger application might be required. ${ }^{36}$

Table 2 provides a summary of the properties, advantages and disadvantages of the filaments used in the production of face shields and masks using FDM technique.

\section{Face shields - materials}

Several tools and components are required to make the face shield. In most cases, only the main body of the face shield is made using AM techniques, to which the remaining accessories are then attached..$^{25}$

The face shield project designed and published by Amin et al. contained a main body made of PLA filament. The protective barrier was a transparency film made of plastic. The face shield was attached to the head with 2 Velcro strips. In order to increase the comfort of use, a sponge was glued to the contact point of the AM-made headband with the forehead. The authors allow the use of Super Sani-Cloth ${ }^{\circledR}$ Germicidal Disposable Wipes (PDI, Woodcliff Lake, USA) for disinfecting and cleaning the face shields. ${ }^{25}$

A model designed by Armijo et al. consisted of 2 elements produced with FDM technology: a headband and a chin piece, which were manufactured using PLA. A transparent polyvinyl chloride (PVC) sheet and a head strap were installed to the headband. It is also possible to use plexiglass or laminating foil as a protective layer. The biggest disadvantage of PVC was the gradual loss of transparency due to the used cleaning solution. Optionally, in order to increase the comfort of use, the authors recommend gluing the foam to the inside of the headband. However, this will make it impossible to reuse the face shield after sterilization, which is done by disassembling the model and then dipping individual elements into the dilute bleach solution, followed by drying. ${ }^{10}$

Wesemann et al. published an article comparing 4 face shield designs. The main body of each of them was made of the biodegradable material Extrudr Green-TEC PRO (Extrudr GmbH, Lauterbach, Germany; carbon filament based on lignin). The protective layer was a transparent foil made of polyethylene terephthalate. In order to keep the face shield on the head, an elastic polyester strap was used. ${ }^{6}$

In the article published by Rendeki et al., scientists tested the disinfection of face shields manufactured with PLA, and the transparent protective layer made of poly(methyl methacrylate) (PMMA). As a disinfectant, they used a solution consisting of sodium perborate and tetraacetylethylenediamine. One disinfection cycle was run at $24^{\circ} \mathrm{C}$ and

Table 2. Properties, advantages and disadvantages of various filaments used for the production of face shields and masks using fused deposition modeling (FDM) technique $6,10,33,37,38$

\begin{tabular}{|c|c|c|c|c|}
\hline Material property & $\begin{array}{c}\text { PLA } \\
\text { polylactic acid }\end{array}$ & $\begin{array}{c}\text { ABS } \\
\text { acrylonitrile butadiene styrene }\end{array}$ & $\begin{array}{c}\text { PET } \\
\text { polyethylene terephthalate }\end{array}$ & $\begin{array}{l}\text { Green-TEC PRO } \\
\text { based on lignin }\end{array}$ \\
\hline Printing temperature & $180-220^{\circ} \mathrm{C}$ & $230-255^{\circ} \mathrm{C}$ & $220-235^{\circ} \mathrm{C}$ & $160-190^{\circ} \mathrm{C}$ \\
\hline Durability & brittle & durable & durable & stable \\
\hline Warp deformation* & little & prone & moderate & little \\
\hline $\begin{array}{l}\text { Autoclave sterilization } \\
\text { - temperature stability }\end{array}$ & volume change & $\begin{array}{l}\text { not recommended - low heat } \\
\text { resistance }\end{array}$ & volume change & dimensionally stable \\
\hline Other & $\begin{array}{c}\text { high-speed low-cost material; } \\
\text { ease of use; completely } \\
\text { biodegradable }\end{array}$ & $\begin{array}{l}\text { possibility of generating toxic } \\
\text { gas fumes during printing; } \\
\text { higher risk of shrinkage during } \\
\text { cooling; not biodegradable }\end{array}$ & $\begin{array}{c}\text { absorbs water - needs to be } \\
\text { stored in specific conditions; } \\
\text { not biodegradable }\end{array}$ & biodegradable \\
\hline
\end{tabular}

*warp deformation - bending towards the energy source caused by inner stresses resulting from the contraction of layer, lack of pre-heating the base plate, non-uniform distribution of temperature inside the build chamber, or improper control of process parameters. ${ }^{39}$ 
lasted for $1 \mathrm{~h}$. Scientists compared the face shields after 0,5 and 10 cycles, in terms of light transmission (using spectrophotometry - measurability of light transmission) and mechanical parameters: flexibility (tensile strength) and brittleness (three-point bending test). In terms of mechanical parameters and visibility, no significant changes were observed after 5 and 10 disinfection cycles. ${ }^{34}$

Perez et al. in their review article brought up the topic of sterilization of items made using AM technology. There are 4 main sterilization techniques commonly used in medicine: autoclave, gamma radiation, hydrogen peroxide gas plasma, and ethylene oxide gas. The following different materials were used for the tests: PC-ABS, ABS-ESD7, ABS-M30i, ABS-M30, and ABSi. From each of them, 30 specimens of the ASTM D638 Type I design were made and sterilized using the above methods. Then, each of the samples (including test samples, not sterilized) was placed in an airtight glass container in $60 \mathrm{~mL}$ of tryptic soy broth and incubated for 14 days. Efficacy evaluation was performed through the observation of tryptic soy broth, which became cloudy after the contamination with fungal or microbial agent. The authors report that individual samples gave a positive test result, but note that the contamination could have occurred after sterilization, during the transfer of the material to the incubation site. Of all the methods, it is worth noting the disadvantages of the autoclave as a method of sterilization of samples made of acrylonitrile butadiene styrene (ABS) derivatives. Humidity and high temperature had a negative effect on this material, leading to indentations, bending and color change. ${ }^{37}$

Sterilization of products made with the FDM technique using ultraviolet light is ineffective because these objects are not watertight or airtight. ${ }^{10}$

Noguera et al. tested possible damage of PPE due to $0.1 \%$ sodium hypochlorite, $70 \%$ ethanol and $\mathrm{H}_{2} \mathrm{O}_{2}$-quaternary ammonium salt mixture. The FDM face shields headbands were made using different materials (including PLA, ABS and polyethylene terephthalate glycol (PETG)) and layer thickness. Visors were made of $0.5 \mathrm{~mm}$ PETG, $0.5 \mathrm{~mm}$ poly(ethylene terephthalate) (PET), $0.75 \mathrm{~mm}$ polycarbonate, or $0.5 \mathrm{~mm} / 0.75 \mathrm{~mm}$ polyethylene glycol (PEG). Disinfection was done using gas soaked in chemical solution, 30 times to headbands and 40 times to visors, followed by spontaneous drying. Researchers observed no physical changes in visual integrity to tested models. ${ }^{40}$

A comparison of commonly used materials for AM is presented in the previous chapter (Table 2).

\section{Discussion}

Most of the analyzed articles were peer-reviewed (excluding the article by McAvoy et al. ${ }^{24}$ ). There are concerns about the technical aspects of AM in this field, in particular FDM, as it was the dominant technology in the analyzed articles. For example, Gomes et al. defines the process speed as $100 \%,{ }^{28}$ which is a relative parameter, and therefore it is difficult to estimate the absolute value of the speed. It should be reported in millimeters per second with acceleration and jerk values. Moreover, it should be taken under consideration that any comparison of production times is also relative as there are many parameters that can be modified to accelerate production, often with (acceptable) decrease of quality.

Neijhoft et al. assessed the quality of the manufactured parts by assigning each FDM machine a different filament color. ${ }^{41}$ Unfortunately, there is no information about the selected production temperatures, but it should be noted that the correct production temperature of PLA varies depending on the color of the filament. ${ }^{42}$ It adds additional complication to the production - instead of quality assurance, each machine should be using individually modified file, for example with a simple marking (number of the machine) on the surface of the model.

Bezek et al. ${ }^{21}$ describe a lot of flaws in their AM-made mask respirators, without any concern about possible errors during the manufacture process. Afinia H800 3D printer (Afinia, Chanhassen, USA) was used in their research. It is a fully enclosed FDM machine and as the picture of their product made of PLA suggest, a problem with the part cooling had occurred. The air cooling the model (during the printing) is warmer due to enclosure (air is taken from the inside); enclosure is used to provide slower cooling of the model (and usually is used without active cooling). There is a possibility that this problem affected PLA mask respirators manufactured by this team.

Parameters that were taken into account during face mask analyses included qualitative fit testing, ${ }^{24}$ quantitative fit testing, ${ }^{19,22,43}$ filtration efficiency, ${ }^{13,21}$ and overall comfort or discomfort (Table 3). ${ }^{18,19,43}$

It is worth emphasizing that the use of $3 \mathrm{D}$ face scanning techniques allows for producing a mask with the highest degree of adhesion, and thus, tightness. ${ }^{5,11,18}$ In order to increase the comfort wearing of a face mask obtained using AM techniques, the use of soft rim, most often made of silicone, has become common. ${ }^{5,22,34}$ Designs of a modified full-face diving mask with AM-made additives and an additional filter were also described. ${ }^{13,23}$ To increase the fit, microwave and hot water can be used, which allows for reshaping of an FDM face mask made of PLA. ${ }^{14}$

The methodology of the papers analyzing face shields varied (Table 4). Only 2 of them compared different types of AM-made face shields, ${ }^{6,44}$ other assessed only 1 type, ${ }^{26,27,45-47}$ and 1 compared N95 mask, goggles and face shield to modified full-face snorkel mask (with AMmade elements). ${ }^{48}$ Number of participants (face shields testers) was between 9 and 300. The observation time was from 30 to $60 \mathrm{~min}$ in most cases, but multiple articles lack this information. The parameters included in the analyzes were COVID-19 infection, ${ }^{27}$ participants' physiological parameters such as blood pressure, ${ }^{48}$ fogging and splash protection, ${ }^{26}$ but most of all, the individual evaluation 
Table 3. Review of validations of additive manufacturing (AM)-made face respirators studies (including AM-made respirators accessories). Analyzed parameters included: qualitative fit testing (QLFT), quantitative fit testing (QNFT), filtration efficiency, and subjective users' opinion on the respirator

\begin{tabular}{|c|c|c|c|c|c|c|c|}
\hline Study & $\begin{array}{l}\text { Compared face } \\
\text { respirators types }\end{array}$ & Parameters & $\begin{array}{l}\text { Number of } \\
\text { participants }\end{array}$ & $\begin{array}{c}\text { Duration } \\
\text { of test }\end{array}$ & Results & $\begin{array}{l}\text { AM technology, } \\
\text { machine, } \\
\text { material }\end{array}$ & Comments \\
\hline McAvoy et al. ${ }^{24}$ & $\begin{array}{l}\text { AM-made mask } \\
\text { frames combined } \\
\text { with masks: } \\
\text { - } 1860 \text { N95 } \\
\text { - } 8210 \text { N95 } \\
\text { - KN95 } \\
\text { - Kimberly-Clark } \\
\text { duckbill }\end{array}$ & $\begin{array}{l}\text { - QLFT } \\
\text { - QNFT }\end{array}$ & 45 & unknown & $\begin{array}{l}\text { passing rates with } \\
\text { the frame in the ab- } \\
\text { sence of the original } \\
\text { straps (in case of pro- } \\
\text { per fit with original } \\
\text { straps) were: } \\
\text { - 1860 N95: } 24 / 30 \\
\text { - KN95: } 11 / 12 \\
\text { - Kimberly-Clark } \\
\text { duckbill } 12 / 15 \\
\text { - 8210: N95 9/9 }\end{array}$ & FDM, no data, PLA & $\begin{array}{l}\text { not every } \\
\text { mask type was } \\
\text { tested on each } \\
\text { participant }\end{array}$ \\
\hline Liu et al. ${ }^{49}$ & $\begin{array}{l}\text { AM-made adapter } \\
\text { for the } 3 \mathrm{M} 7501 \text { and } \\
3 \mathrm{M} 6200 \text { elasto- } \\
\text { meric respirators } \\
\text { to interface with } \\
\text { anesthesia circuit } \\
\text { filters }\end{array}$ & $\begin{array}{l}\text { - end-tidal carbon } \\
\text { dioxide } \\
\text { - respiratory rate } \\
\text { - self-reported } \\
\text { of discomfort }\end{array}$ & 8 & $60 \mathrm{~min}$ & $\begin{array}{l}\text { mean end-tidal } \\
\text { carbon dioxide and } \\
\text { mean respiratory rate } \\
\text { were not statistically } \\
\text { different }(p>0.05) \text {; } \\
4 / 8(50.0 \%) \text { subjects } \\
\text { self-reported discom- } \\
\text { fort }\end{array}$ & $\begin{array}{l}\text { FDM, Ultimaker } \\
\text { S5, PLA (Premium } \\
\text { PLA, Formfutura } \\
\text { BV) }\end{array}$ & $\begin{array}{l}\text { all participants } \\
\text { passed quali- } \\
\text { tative positive } \\
\text { and negative } \\
\text { pressure leak } \\
\text { testing, } \\
\text { quantitative } \\
\text { and qualitative } \\
\text { fit testing }\end{array}$ \\
\hline Bezek et al. ${ }^{21}$ & $\begin{array}{l}\text { AM-made masks: } \\
\text { - Montana } \\
\text { - Factoria } \\
\text { - Stopgap; } \\
\text { masks were manu- } \\
\text { factured once with } \\
\text { each method }\end{array}$ & $\begin{array}{l}\text { - filtration effi- } \\
\text { ciency } \\
\text { - masks were } \\
\text { compared } \\
\text { before and after } \\
\text { post-processing }\end{array}$ & $\begin{array}{l}\text { not appli- } \\
\text { cable }\end{array}$ & $\begin{array}{l}\text { not appli- } \\
\text { cable }\end{array}$ & $\begin{array}{l}\text { Factoria respirator } \\
\text { provided the highest } \\
\text { observed performan- } \\
\text { ce, with a filtration } \\
\text { efficiency } 90-95 \% \text {; } \\
\text { post-processing mo- } \\
\text { difications to the pro- } \\
\text { duced respirators } \\
\text { generally improved } \\
\text { performance }\end{array}$ & $\begin{array}{l}\text { FDM, Afinia H800, } \\
\text { ABS and PLA; } \\
\text { SLS; DTM Sinter- } \\
\text { station } 2500 \text { Plus, } \\
\text { nylon-12; } \\
\text { FDM, Fortus } \\
400 \text { mc, ULTEM } \\
9085\end{array}$ & - \\
\hline $\begin{array}{l}\text { Piombino } \\
\text { et al. }{ }^{18}\end{array}$ & $\begin{array}{l}\text { AM-made person- } \\
\text {-tailored Mask 3D }\end{array}$ & $\begin{array}{l}\text { - skin comfort } \\
\text { - respiratory } \\
\text { comfort } \\
\text { - quality of work } \\
\text { shift whilst we- } \\
\text { aring the mask } \\
\text { (five-point Likert } \\
\text { scale) in } 3 \text { locali- } \\
\text { zations: surgery } \\
\text { room, medical } \\
\text { clinic and maxillo- } \\
\text { facial surgery ward }\end{array}$ & 6 & 7 days & $\begin{array}{l}\text { overall rating: } \\
\text { - in the surgery } \\
\text { room: } 3 / 6 \text { very } \\
\text { good, } 3 / 6 \text { good; } \\
\text { - in the medical cli- } \\
\text { nic: } 2 / 6 \text { very good, } \\
4 / 6 \text { good; } \\
\text { - in the maxillofacial } \\
\text { surgery ward: } \\
2 / 6 \text { very good, } \\
4 / 6 \text { good }\end{array}$ & $\begin{array}{l}\text { FDM, Ultimaker } 2 \\
\text { Extended+, TPU } \\
\text { (Rubber TPU D27 } \\
\text { (Bioflex, Bioalfa, } \\
\text { Soria Vecchia) } \\
\text { and PLA (Eco } \\
\text { PLA, 3DJake Italia, } \\
\text { Niceshops GmbH) }\end{array}$ & $\begin{array}{l}\text { for such small } \\
\text { test group } \\
\text { results should } \\
\text { be presented } \\
\text { individually } \\
\text { for each test } \\
\text { subject }\end{array}$ \\
\hline Davies et al. ${ }^{16}$ & $\begin{array}{l}\text { AM-made modified } \\
\text { Copper 3D Nano- } \\
\text { hack (added a cen- } \\
\text { tral port to permit } \\
\text { attachment of bron- } \\
\text { choscope adapter) }\end{array}$ & $\begin{array}{l}\text { - spread } \\
\text { of phosphor } \\
\text { fluorescent dye } \\
\text { during simulated } \\
\text { bronchoscopy }\end{array}$ & 1 & $\begin{array}{l}\text { not appli- } \\
\text { cable }\end{array}$ & $\begin{array}{l}\text { AM-made mask } \\
\text { reduced to zero } \\
\text { spread of phosphor } \\
\text { fluorescent dye }\end{array}$ & $\begin{array}{l}\text { SLA, Form 2, } \\
\text { biocompatible } \\
\text { photopolymer } \\
\text { resin (Dental SG, } \\
\text { Formlabs Inc.) }\end{array}$ & - \\
\hline
\end{tabular}


Table 3. Review of validations of additive manufacturing (AM)-made face respirators studies (including AM-made respirators accessories). Analyzed parameters included: qualitative fit testing (QLFT), quantitative fit testing (QNFT), filtration efficiency, subjective users' opinion on the respirator - cont

\begin{tabular}{|c|c|c|c|c|c|c|c|}
\hline Study & $\begin{array}{l}\text { Compared face } \\
\text { respirators types }\end{array}$ & Parameters & $\begin{array}{l}\text { Number of } \\
\text { participants }\end{array}$ & $\begin{array}{l}\text { Duration } \\
\text { of test }\end{array}$ & Results & $\begin{array}{l}\text { AM technology, } \\
\text { machine, } \\
\text { material }\end{array}$ & Comments \\
\hline $\begin{array}{l}\text { Imbrie-Moore } \\
\text { et al. }{ }^{22}\end{array}$ & $\begin{array}{l}\text { AM-made cartridge } \\
\text { with an inner } \\
\text { ridge and soft } \\
\text { silicone base used } \\
\text { to seal } 1 / 4 \text { of a } 3 \mathrm{M} \\
1860 \text { N95 mask }\end{array}$ & - QNFT & 6 & $\begin{array}{l}\text { not applica- } \\
\text { ble/no data }\end{array}$ & $\begin{array}{l}\text { overall fit factor was } \\
148 \pm 29\end{array}$ & $\begin{array}{l}\text { SLA, Carbon M2, } \\
\text { biocompatible } \\
\text { Silicone (SIL 30, } \\
\text { Carbon) and } \\
\text { Multipurpose } \\
\text { Polyurethane } \\
\text { (MPU 100, Car- } \\
\text { bon) }\end{array}$ & - \\
\hline Ballard et al. ${ }^{43}$ & $\begin{array}{l}\text { AM-made } 5 \text { rigid } \\
\text { and } 5 \text { flexible mask } \\
\text { prototypes of own } \\
\text { design }\end{array}$ & $\begin{array}{l}\text { - QNFT } \\
\text { - comfort level }\end{array}$ & 4 & $7 \mathrm{~min}$ & $\begin{array}{l}2 \text { designs produced } \\
\text { with flexible poly- } \\
\text { mers passed QNFT } \\
\text { with a mean fit factor } \\
\text { of 138; } \\
\text { comfort level was } \\
\text { similar to N95 respi- } \\
\text { rators }\end{array}$ & $\begin{array}{l}\text { SLA, Form 2; } \\
\text { elastic and } \\
\text { flexible (V2) } \\
\text { resins (FormLabs); } \\
\text { PolyJet; Stratasys } \\
\text { J750; Agilus30, } \\
\text { Biocompatible } \\
\text { Clear MED610, } \\
\text { Tango and Vero; } \\
\text { FDM Makerbot } \\
\text { 5th Gen; PLA }\end{array}$ & - \\
\hline George et al. ${ }^{50}$ & $\begin{array}{l}\text { SNAP - AM-made, } \\
\text { single-use, valved } \\
\text { endoscopic port, } \\
\text { retrofitted to any } \\
\text { surgical mask }\end{array}$ & $\begin{array}{l}\text { - spread of fluore- } \\
\text { scein } \\
\text { - adverse effects }\end{array}$ & 9 & no data & $\begin{array}{l}\text { no spread of fluore- } \\
\text { scein; } \\
\text { no adverse effects }\end{array}$ & $\begin{array}{l}\text { FDM, Flashforge } \\
\text { Creator Pro 3D, } \\
\text { no data }\end{array}$ & - \\
\hline $\mathrm{Ng}$ et al. ${ }^{19}$ & $\begin{array}{l}\text { AM-made reusable } \\
\text { silicone-molded } \\
\text { face mask (SSM), } \\
\text { N95 3M face mask }\end{array}$ & $\begin{array}{l}\text { - QNFT } \\
\text { - comfort } \\
\text { - breathability }\end{array}$ & 40 & $\begin{array}{l}\text { not applica- } \\
\text { ble/no data }\end{array}$ & $\begin{array}{l}\text { SSM scored } 3.5 / 5 \text { and } \\
4 / 5 \text { for comfort and } \\
\text { breathability; } \\
\text { overall passing rates } \\
\text { in disposable and } \\
\text { SSM respirators } \\
\text { on QNFT were } 65 \% \\
\text { and 100\% }\end{array}$ & $\begin{array}{l}\text { Mold: FDM; } \\
\text { PRUSA I3 MK3S, } \\
\text { no data; Harness } \\
\text { FDM, PRUSA I3 } \\
\text { MK3S, PLA and } \\
\text { PETG }\end{array}$ & - \\
\hline Felinska et al. ${ }^{23}$ & $\begin{array}{l}\text { modified Easybreath } \\
\text { full-face diving mask } \\
\text { (addition of filter), } \\
\text { standard surgical } \\
\text { mask }\end{array}$ & $\begin{array}{l}\text { - time until profi- } \\
\text { ciency } \\
\text { - number } \\
\text { of attempts } \\
\text { until proficiency } \\
\text { (laparoscopic } \\
\text { suturing) } \\
\text { - Objective Struc- } \\
\text { tured Asses- } \\
\text { sment of Techni- } \\
\text { cal Skills scores } \\
\text { (laparoscopic } \\
\text { cholecystecto- } \\
\text { my) } \\
\text { - comfort }\end{array}$ & 40 & $\begin{array}{l}\text { not appli- } \\
\text { cable }\end{array}$ & $\begin{array}{l}\text { no statistically signifi- } \\
\text { cant difference }\end{array}$ & FDM, no data, PLA & $\begin{array}{l}\text { partici- } \\
\text { pants were } \\
\text { laparoscopically } \\
\text { naive medical } \\
\text { students }\end{array}$ \\
\hline Helman et al. ${ }^{17}$ & $\begin{array}{l}\text { AM-made endosco- } \\
\text { pic mask }\end{array}$ & $\begin{array}{l}\text { - surgical freedom } \\
\text { - test of aerosoli- } \\
\text { zation }\end{array}$ & $\begin{array}{l}\text { not appli- } \\
\text { cable }\end{array}$ & $\begin{array}{l}\text { not applica- } \\
\text { ble/no data }\end{array}$ & $\begin{array}{l}\text { mask reduced partic- } \\
\text { le spillage: } \\
\text { - by } 86 \% \text { for anteriol } \\
\text { surgery } \\
\text { - by } 71 \% \text { for poste- } \\
\text { rior surgery } \\
\text { - the trocar system } \\
\text { reduced spillage } \\
\text { by } 97 \% \text {; } \\
\text { mask allowed for } \\
\text { an appropriate surgi- } \\
\text { cal range of motion }\end{array}$ & $\begin{array}{l}\text { FDM, Ultimaker } 2 \\
\text { and Pulse } \\
\text { XE, TPU and Poly- } \\
\text { amide } 12 \text { (NylonX, } \\
\text { MatterHackers) }\end{array}$ & $\begin{array}{l}\text { tested on } 2 \text { ca- } \\
\text { davers }\end{array}$ \\
\hline
\end{tabular}

FDM - fused deposition modeling; PLA - polylactic acid; SSM - simple silicone mask; TPU - thermoplastic polyurethane. 
Table 4. Review of validations of additive manufacturing (AM)-made face shields studies. Analyzed parameters included: fogging testing, splash protection, users' body parameters like respiratory rate, and subjective users' opinion on the respirator

\begin{tabular}{|c|c|c|c|c|c|c|}
\hline Study & $\begin{array}{l}\text { Compared } \\
\text { AM-made face } \\
\text { shields types }\end{array}$ & Parameters & $\begin{array}{l}\text { Number of } \\
\text { participants }\end{array}$ & $\begin{array}{l}\text { Duration } \\
\text { of test }\end{array}$ & Results & $\begin{array}{c}\text { AM technology, } \\
\text { machine, materials }\end{array}$ \\
\hline Wesemann et al. ${ }^{6}$ & $\begin{array}{l}\text { RC1, RC2, Bud- } \\
\text { men V3, Easy 3D }\end{array}$ & $\begin{array}{l}\text { - fit } \\
\text { - comfort } \\
\text { - wearing } \\
\text { - protection } \\
\text { - overall evaluation (Visual } \\
\text { Analogue Scale (VAS)) }\end{array}$ & 10 & $60 \mathrm{~min}$ & $\begin{array}{l}\text { overall Easy } 3 D(87 \pm 4) \text { and } \\
\text { RC2 }(81 \pm 5) \text { received the hi- } \\
\text { ghest scores, which differed } \\
\text { significantly from those for } \\
\text { RC1 }(63 \pm 6) \text { and Budmen } \\
\text { V3 }(56 \pm 4)(p=0.001)\end{array}$ & $\begin{array}{l}\text { FDM, Prusa I3 } \\
\text { MK3S, PLA (GreenTEC } \\
\text { PRO, Extrudr) }\end{array}$ \\
\hline Sapoval et al. ${ }^{45}$ & $\begin{array}{l}\text { 3D4Care face } \\
\text { shield (modified } \\
\text { RC2) }\end{array}$ & $\begin{array}{l}\text { - ability to perform the assi- } \\
\text { gned intervention as usual } \\
\text { - quality of visual comfort } \\
\text { - musculo-skeletal tolerance } \\
\text { (1-5 Likert scale) }\end{array}$ & 38 & $\begin{array}{l}\text { mean } \\
\text { time } \\
59 \text { min }\end{array}$ & $\begin{array}{l}\text { ability to perform the assi- } \\
\text { gned intervention as usual } \\
\text { was } 1.7 \pm 0.8(S D) \\
\text { mean visual tolerance } \\
\text { rating was } 1.6 \pm 0.7(S D) \text {; } \\
\text { the mean tolerability rating } \\
\text { was } 1.4 \pm 0.7 \text { (SD) }\end{array}$ & $\begin{array}{l}\text { FDM, no data, PLA } \\
\text { and } A B S\end{array}$ \\
\hline Chaturvedi et al. ${ }^{47}$ & $\begin{array}{l}\text { own unnamed } \\
\text { design }\end{array}$ & $\begin{array}{l}\text { i.a.: } \\
\text { - ease of use } \\
\text { - visibility during the pro- } \\
\text { cedures } \\
\text { - comfort during the pro- } \\
\text { cedures } \\
\text { - ease of assembly } \\
\text { - ease of disassembly } \\
\text { - ease of cleaning } \\
\text { - confidence to reuse } \\
\text { (0-10 scale) }\end{array}$ & 37 & no data & $\begin{array}{l}\text { overall mean score was } \\
7.92 \pm 2.13(\mathrm{SD})\end{array}$ & FDM, no data, PLA \\
\hline Kusano et al. ${ }^{48}$ & $\begin{array}{l}\text { set (N95 mask, } \\
\text { goggle and face } \\
\text { shield), modified } \\
\text { full-face snorkel } \\
\text { mask (with AM- } \\
\text {-made elements) }\end{array}$ & $\begin{array}{l}\text { - blood pressure } \\
\text { - pulse } \\
\text { - oxygen saturation } \\
\text { - respiratory rate (assessed } \\
\text { twice: before and after the } \\
\text { procedure of endoscopy) }\end{array}$ & 9 & $30 \mathrm{~min}$ & $\begin{array}{l}\text { statistically significant: set } \\
\text { decreased oxygen satura- } \\
\text { tion by } 0.9 \text { percent point; } \\
\text { modified snorkel mask } \\
\text { increased respiratory rate } \\
\text { by } 1.5 \text { breaths/min }\end{array}$ & no data \\
\hline $\begin{array}{l}\text { Mostaghimi } \\
\text { et al. }{ }^{26}\end{array}$ & $\begin{array}{l}\text { PanFab face } \\
\text { shield (modified } \\
\text { RC2) }\end{array}$ & $\begin{array}{l}\text { - fogging testing (min. } \\
30 \text { min) } \\
\text { - testing splash protection } \\
\text { (subjective) } \\
\text { - durability } \\
\text { - ease of use } \\
\text { - comfort } \\
\text { (five-point Likert scale) }\end{array}$ & 92 & $\begin{array}{l}30- \\
60 \mathrm{~min}\end{array}$ & $\begin{array}{l}\text { average scores were: } \\
\text { - splash protection - } 4.7 \\
\text { - durability }-4.6 \\
\text { - ease of use }-4.3 \\
\text { - comfort }-4.4\end{array}$ & $\begin{array}{l}\text { FDM, Ender } 3 \text { Pro, PLA } \\
\text { (Hatchbox) }\end{array}$ \\
\hline Huang et al. ${ }^{27}$ & $\begin{array}{l}\text { own unnamed } \\
\text { design }\end{array}$ & COVID-19 infection & over 300 & no data & $\begin{array}{l}\text { none of participants were } \\
\text { reported to be infected } \\
\text { with COVID-19 }\end{array}$ & SLA, no data \\
\hline Desselle et al. ${ }^{44}$ & $\begin{array}{l}\text { Prusa RC3, MSD } \\
\text { headband }\end{array}$ & $\begin{array}{l}\text { - presence of visible con- } \\
\text { tamination on the face and } \\
\text { forehead }\end{array}$ & $\begin{array}{l}5 \text { partici- } \\
\text { pants, } \\
10 \text { reviewers }\end{array}$ & no data & $\begin{array}{l}\text { overall pass rates: MSD } \\
\text { headband 75\%, Prusa } \\
\text { RC3 } 100 \%\end{array}$ & no data \\
\hline
\end{tabular}

SD - standard deviation; FDM - fused deposition modeling; PLA - polylactic acid; ABS - acrylonitrile butadiene styrene.

of the face shield model by participants. ${ }^{6,26,45-47}$ Most of the researches tested only if AM-made face shields are comfortable to wear, not if they protect against infection (especially COVID-19). Huang et al. mentioned that none of the users of their face shield were reported to be infected with COVID-19, but they did not report the methodology for this finding. There is no information if the participants of that study were tested for SARS-CoV-2 on a regular 
basis. There is lack of control group of non-AM-made shields users to determine the true usefulness of this PPE. ${ }^{27}$

Wesemann et al. found out that Easy 3D (https://www. thingiverse.com/thing:4233193) and Prusa RC2 achieved better overall score than Prusa RC1 and Budmen V3 (IC3D Printers, Columbus, USA). ${ }^{6}$ Desselle et al. proved that the Prusa RC3 is better than the MSD headband (University of Melbourne, Australia). ${ }^{44}$ In the remaining papers, researchers tested 3D4Care face shield (modified RC2; 3D4Care, Paris, France), PanFab face shield (also modified RC2; Greater Boston Pandemic Fabrication Team, USA) and other, unnamed designs. All of them received a subjective positive rating.

Proper disinfection, which allows AM-made PPE to be reused, is a major challenge. The polymers used for FDM production are prone to high temperature and humidity (autoclave). Therefore, the most common decontamination method, especially against SARS-CoV-2, was the use of $96 \%$ ethanol, $70 \%$ ethanol, $70 \%$ isopropanol, $0.85 \%$ or $0.1 \%$ sodium hypochlorite, $3 \% \mathrm{H}_{2} \mathrm{O}_{2}, 10 \%$ bleach and quaternary ammonium, or $\mathrm{H}_{2} \mathrm{O}_{2}$-quaternary ammonium salt mixture. ${ }^{36,40}$

The quality control of the finished part should be considered. It is difficult to compare between the analyzed papers regarding which models are the fastest and cheapest to produce, due to the differences between used machines, materials, process parameters and models included in the comparison, and is beyond the scope of this article.

The authors of the analyzed articles did not provide any information whether the used materials and processes are certified (or verified) for skin contact, apart from Swennen et al. (PA11-SX 1450 which meets USP Class VI requirements). ${ }^{11}$ The additional research of materials used in the reviewed articles did not reveal any other skin-safe materials.

\section{Conclusions}

In the design phase, it is crucial to focus on effective protection, comfortable wearing and the possibility of easy production of the PPE. It is also commendable to make the project publicly available for free, with open source data. In addition to helping to produce PPE, it encourages global collaboration to improve the design. The current situation requires efficient cooperation of the scientific community to overcome the challenges posed by the COVID-19 pandemic.

The face masks are the most important element of PPE, as the transmission of SARS-CoV-2 occurs primarily by droplets. They can be produced with AM to replace shortages, but also can be personalized for potential better comfort or protection and a better fit than commercially available ones (e.g., SSM respirator). Presumably, personalized masks would be more expensive, and in a crisis such like the COVID-19 pandemic, there would be no time or resources for it.

Unfortunately, most researchers have only tested 1 type of AM-made respirators and did not compare them with other respirators (AM-made or commercially available). In comparison, the Factoria respirator provided the highest performance observed, with a filtration efficiency of $90-95 \%$.

Furthermore, the face shield is an important part of the PPE utilized during the COVID-19 pandemic. It can be concluded that, with certain limitations, AM-made face shields can be designed and manufactured. There is no research comparing commercially available face shields and AM-made ones. Basing on insufficient data (mainly questionnaires), RC2 (and its newer version - RC3 or their modifications) is the best choice for the FDM face shield model. It has good fitting and wearing comfort, and offers space for additional PPE and stacking possibility.

Additive manufacturing is not adequate for high-volume production of PPE, but it is still useful. It has the potential to temporarily fix the broken supply chains and it is useful in designing new PPE products. It allows for the production of personalized PPE or accessories to improve existing PPE (e.g., frames for better fit of face masks). A significant limitation of AM-made PPE in the analyzed papers is the lack of data on the safety of skin contact of the produced PPE.

\section{ORCID iDs}

Jakub Rzeszuto (D) https://orcid.org/0000-0002-8417-7318 Patryk Kaczor (D) https://orcid.org/0000-0002-9359-157X Bernadetta Kosztulska (D) https://orcid.org/0000-0001-8408-5811 Iwona Handzlik (D) https://orcid.org/0000-0001-5592-4639 Szymon Suwała (D) https://orcid.org/0000-0002-5865-8484 Roman Junik (1) https://orcid.org/0000-0001-9604-5569

\section{References}

1. WHO Director-General's opening remarks at the media briefing on COVID-19 - 11 March 2020. https://www.who.int/director-general/ speeches/detail/who-director-general-s-opening-remarks-at-themedia-briefing-on-covid-19---11-march-2020. Accessed June 22, 2021.

2. Wang D, Hu B, Hu C, et al. Clinical characteristics of 138 hospitalized patients with 2019 novel coronavirus-infected pneumonia in Wuhan, China. JAMA. 2020;323(11):1061. doi:10.1001/jama.2020.1585

3. Lee PI, Hsueh PR. Emerging threats from zoonotic coronavirusesfrom SARS and MERS to 2019-nCoV. J Microbiol Immunol Infect. 2020; 53(3):365-367. doi:10.1016/j.jmii.2020.02.001

4. Advice for the public. https://www.who.int/emergencies/diseases/ novel-coronavirus-2019/advice-for-public. Accessed June 30, 2021.

5. Shaheen E, Willaert R, Miclotte I, Coropciuc R, Bila M, Politis C. A novel fully automatic design approach of a 3D printed face specific mask: Proof of concept. PLoS One. 2020;15(12):e0243388. doi:10.1371/journal. pone. 0243388

6. Wesemann C, Pieralli S, Fretwurst T, et al. 3D printed protective equipment during COVID-19 pandemic. Materials (Basel). 2020;13(8):1997. doi:10.3390/ma13081997

7. Roberge RJ. Face shields for infection control: A review. J Occup Environ Hyg. 2016;13(4):235-242. doi:10.1080/15459624.2015.1095302

8. F42 Committee. Terminology for Additive Manufacturing Technologies. West Conshohocken, USA: ASTM International, 2013. https://web.mit. edu/2.810/www/files/readings/AdditiveManufacturingTerminology. pdf/doi:10.1520/F2792-12A

9. Jiménez $M$, Romero $L$, Domínguez IA, Espinosa $M$ del $M$, Domínguez M. Additive manufacturing technologies: An overview about 3D printing methods and future prospects. Complexity. 2019;2019:1-30. doi:10.1155/2019/9656938

10. Armijo PR, Markin NW, Nguyen S, et al. 3D printing of face shields to meet the immediate need for PPE in an anesthesiology department during the COVID-19 pandemic. Am JInfect Control. 2021;49(3):302-308. doi:10.1016/j.ajic.2020.07.037 
11. Swennen GRJ, Pottel L, Haers PE. Custom-made 3D-printed face masks in case of pandemic crisis situations with a lack of commercially available FFP2/3 masks. Int J Oral Maxillofac Surg. 2020;49(5): 673-677. doi:10.1016/j.ijom.2020.03.015

12. Allam M, Cai S, Ganesh S, et al. COVID-19 diagnostics, tools, and prevention. Diagnostics (Basel). 2020;10(6):409. doi:10.3390/diagnostics 10060409

13. Gierthmuehlen M, Kuhlenkoetter B, Parpaley $Y$, Gierthmuehlen S, Köhler D, Dellweg D. Evaluation and discussion of handmade facemasks and commercial diving-equipment as personal protection in pandemic scenarios. PLoS One. 2020;15(8):e0237899. doi:10.1371/ journal.pone.0237899

14. Thingiverse.com. HEPA Covid coronavirus face mask by Kvatthro. https://www.thingiverse.com/thing:4222563. Accessed August 3, 2021.

15. 1910.134 App A - Fit Testing Procedures (Mandatory). Occupational Safety and Health Administration. https://www.osha.gov/lawsregs/regulations/standardnumber/1910/1910.134AppA. Accessed November 7, 2021

16. Davies JC, Chan HHL, Gilbert RW, Irish JC. Nasal endoscopy during the COVID-19 pandemic: Mitigating risk with 3D printed masks. Laryngoscope. 2020;130(11):2561-2563. doi:10.1002/lary.29004

17. Helman SN, Soriano RM, Tomov ML, et al. Ventilated upper airway endoscopic endonasal procedure mask: surgical safety in the COVID-19 era. Oper Neurosurg (Hagerstown). 2020;19(3):271-280. doi:10.1093/ ons/opaa168

18. Piombino $P$, Committeri $U$, Norino $G$, et al. Facing COVID-19 pandemic: Development of custom-made face mask with rapid prototyping system. J Infect Dev Ctries. 2021;15(1):51-57. doi:10.3855/jidc.13384

19. Ng WCK, Mbadjeu Hondjeu AR, Syrett $A$, et al. Subject validation of reusable N95 stop-gap filtering facepiece respirators in COVID-19 pandemic. PLoS One. 2020;15(11):e0242304. doi:10.1371/journal.pone. 0242304

20. Anwari V, Ng WCK, Mbadjeu Hondjeu AR, et al. Development, manufacturing, and preliminary validation of a reusable half-face respirator during the COVID-19 pandemic. PLoS One. 2021;16(3):e0247575. doi:10.1371/journal.pone.0247575

21. Bezek LB, Pan J, Harb C, et al. Additively manufactured respirators: quantifying particle transmission and identifying system-level challenges for improving filtration efficiency. JManufSyst. 2021;60:762-773. doi:10.1016/j.jmsy.2021.01.002

22. Imbrie-Moore AM, Park MH, Zhu Y, Paulsen MJ, Wang H, Woo YJ. Quadrupling the N95 supply during the COVID-19 crisis with an innovative 3D-printed mask adaptor. Healthcare (Basel). 2020;8(3):225. doi:10.3390/healthcare8030225

23. Felinska EA, Chen ZW, Fuchs TE, et al. Surgical performance is not negatively impacted by wearing a commercial full-face mask with ad hoc 3D-printed filter connection as a substitute for personal protective equipment during the COVID-19 pandemic: A randomized controlled cross-over trial. J Clin Med. 2021;10(3):550. doi:10.3390/ jcm10030550

24. McAvoy M, Bui ATN, Hansen C, et al. 3D Printed frames to enable reuse and improve the fit of $\mathrm{N} 95$ and KN95 respirators. BMC Biomed Eng. 2021;3(1):10. doi:10.1186/s42490-021-00055-7

25. Amin D, Nguyen N, Roser SM, Abramowicz S. 3D printing of face shields during COVID-19 pandemic: A technical note. J Oral Maxillofac Surg. 2020;78(8):1275-1278. doi:10.1016/j.joms.2020.04.040

26. Mostaghimi A, Antonini MJ, Plana D, et al. Regulatory and safety considerations in deploying a locally fabricated, reusable face shield in a hospital responding to the COVID-19 pandemic. Med (NY). 2020; 1(1):139-151.e4. doi:10.1016/j.medj.2020.06.003

27. Huang $X L$, Yang JR, Sun $Y X$, et al. Novel combined shield design for eye and face protection from COVID-19. Adv Manuf. 2021:1;1-6. doi:10.1007/s40436-020-00333-y

28. Gomes B de A, Queiroz FLC, Pereira PL de O, et al. In-house threedimensional printing workflow for face shield during COVID-19 pandemic. J Craniofac Surg. 2020;31(6):e652-e653. doi:10.1097/SCS.00000 00000006723

29. Lemarteleur $V$, Fouquet $V$, Le Goff $S$, et al. 3D-printed protected face shields for health care workers in Covid-19 pandemic. Am JInfect Control. 2021;49(3):389-391. doi:10.1016/j.ajic.2020.08.005
30. Budmen ${ }^{\circledast}$ Face Shield. Budmen ${ }^{\circledR}$ Industries. https://budmen.com/ face-shield/. Published March 23, 2020. Accessed June 30, 2021.

31. BWH/PanFab Mk 1 Face Shield. https://www.panfab.org/bwh-panfab-face-shield. Accessed June 30, 2021.

32. Thingiverse.com. Easy 3D printed Face Shield by HanochH. https:// www.thingiverse.com/thing:4233193. Accessed June 30, 2021.

33. He H, Gao M, Illés B, Molnar K. 3D Printed and electrospun, transparent, hierarchical polylactic acid mask nanoporous filter. Int J Bioprint. 2020;6(4):278. doi:10.18063/ijb.v6i4.278

34. Rendeki S, Nagy B, Bene M, et al. An overview on personal protective equipment (PPE) fabricated with additive manufacturing technologies in the era of COVID-19 pandemic. Polymers (Basel). 2020;12(11): 2703. doi:10.3390/polym12112703

35. Vaňková $E$, Kašparová $P$, Khun J, et al. Polylactic acid as a suitable material for 3D printing of protective masks in times of COVID-19 pandemic. PeerJ. 2020;8:e10259. doi:10.7717/peerj.10259

36. Welch JL, Xiang J, Mackin SR, et al. Inactivation of severe acute respiratory coronavirus virus 2 (SARS-CoV-2) and diverse RNA and DNA viruses on three-dimensionally printed surgical mask materials. Infect Control Hosp Epidemiol. 2021;42(3):253-260. doi:10.1017/ice.2020.417

37. Perez MA, Block M, Espalin D, et al. Sterilization of FDM-manufactured parts. http://utw10945.utweb.utexas.edu/Manuscripts/2012/201221-Perez.pdf. The University of Texas at El Paso, USA. Accepted August 15, 2012, Accessed June 30, 2021.

38. Foo GL, Kwek EBK. Are three-dimensional printed models useful for preoperative planning of tibial plafond fractures? J Foot Ankle Surg. 2019;58(4):723-729. doi:10.1053/j.jfas.2018.12.005

39. Panda BN, Shankhwar K, Garg A, Jian Z. Performance evaluation of warping characteristic of fused deposition modelling process. Int J Adv Manuf Technol. 2017;88(5-8):1799-1811. doi:10.1007/s00170016-8914-8

40. Noguera SV, Espinoza EPS, Côrtes MF, et al. Disinfection of 3D-printed protective face shield during COVID-19 pandemic. Am J Infect Control. 2021;49(4):512-515. doi:10.1016/j.ajic.2020.10.008

41. Neijhoft J, Viertmann T, Meier S, et al. Manufacturing and supply of face shields in hospital operation in case of unclear and confirmed COVID-19 infection status of patients. Eur J Trauma Emerg Surg. 2020;46(4):743-745. doi:10.1007/s00068-020-01392-3

42. Wittbrodt B, Pearce JM. The effects of PLA color on material properties of 3-D printed components. Additive Manufacturing. 2015;8:110-116. doi:10.1016/j.addma.2015.09.006

43. Ballard DH, Jammalamadaka U, Meacham KW, et al. Quantitative fit tested $\mathrm{N} 95$ respirator-alternatives generated with $\mathrm{CT}$ imaging and 3D printing: A response to potential shortages during the COVID-19 pandemic. Acad Radiol. 2021;28(2):158-165. doi:10.1016/j.acra.2020.11.005

44. Desselle MR, Kirrane M, Chao IT, et al. Evaluating the safety and effectiveness of novel personal protective equipment during the COVID-19 pandemic. Med JAust. 2021;214(11):496-499.e1. doi:10.5694/mja2.51091

45. Sapoval M, Gaultier AL, Del Giudice C, et al. 3D-printed face protective shield in interventional radiology: Evaluation of an immediate solution in the era of COVID-19 pandemic. Diagn Interv Imaging. 2020;101(6):413-415. doi:10.1016/j.diii.2020.04.004

46. Celik HK, Kose O, Ulmeanu ME, Rennie AEW, Abram TN, Akinci I. Design and additive manufacturing of medical face shield for healthcare workers battling coronavirus (COVID-19). Int J Bioprint. 2020; 6(4):286. doi:10.18063/ijb.v6i4.286

47. Chaturvedi S, Gupta A, Krishnan SV, Bhat AK. Design, usage and review of a cost effective and innovative face shield in a tertiary care teaching hospital during COVID-19 pandemic. J Orthop. 2020;21: 331-336. doi:10.1016/j.jor.2020.07.003

48. Kusano C, Goddard J, Gotoda T. Experience for use of modified fullface snorkel mask as personal protective equipment during endoscopic procedures in the era of coronavirus disease pandemic. Dig Endosc. 2020;32(6):1000. doi:10.1111/den.13784

49. Liu DCY, Koo TH, Wong JKK, et al. Adapting re-usable elastomeric respirators to utilise anaesthesia circuit filters using a 3D-printed adaptor: A potential alternative to address N95 shortages during the COVID-19 pandemic. Anaesthesia. 2020;75(8):1022-1027. doi:10. 1111/anae. 15108

50. George A, Prince M, Coulson C. Safe nasendoscopy assisted procedure in the post-COVID-19 pandemic era. Clin Otolaryngol. 2020; 45(5):844-846. doi:10.1111/coa.13591 